\title{
MOUTHWASH JUS BUAH NANAS (Ananas comosus L. Merr) TERHADAP BAKTERI Streptococcus mutans
}

1| Sri Wahyuningsih, 2| Nielma Auliah, 3| Salwi

Email : sriwahyuningsih1004@gmail.com

\begin{abstract}
This research aimed to determine the formulation of pineapple juice into mouthwash and to investigate antibacterial activity against Streptococcus mutans. This was an experimental design method, it started by formulating pineapple juice (Ananas comosus L.Merr) into mouthwash and testing the activity of bacteria using the agar diffusion method to determine the inhibition zone. The research result showed that pineapple juice (Ananas comosus L.Merr) can be formulated into mouthwash with a concentration of 5\%; 10\%; and $15 \%$ and there was no significant difference after the stability test. The mouthwash also has antibacterial activity against Streptococcus mutans with a zone of inhibition for a concentration of 5\%; 10\% and 15\%, respectively $8.6 \mathrm{~mm}$; $9.4 \mathrm{~mm}$; and 9.7 $\mathrm{mm}$. Antibacterial activity of pineapple juice mouthwash against Streptococcus mutans showed a moderate inhibition zone category.
\end{abstract}

ARTICLE INFO

Keywords:

Pineapple juice; Mouthwash;

Streptococcus mutans

DOI:

$\underline{10.24252 / \text { kesehatan.v13i2.16423 }}$

\section{Pendahuluan}

Kesehatan mulut dan gigi terutama rongga mulut termasuk salah satu hal penting bagi manusia [1]. Masalah kesehatan gigi dan mulut seperti bau mulut (halitosis), karies gigi dan radang gusi, hampir menjadi masalah bagi semua manusia. Hal ini disebabkan karena tempat pertumbuhan mikroorganisme sebagai penyebab infeksi adalah rongga mulut sehingga akan mempengaruhi keadaan kesehatan (2). Dalam rongga mulut, beragam mikroorganisme dapat ditemukan dan hidup, salah satu yang sering ditemukan adalah bakteri [3].

Streptococcus mutans merupakan salah satu bakteri yang ditemukan dan hidup dalam rongga mulut [1]. Salah satu penyakit infeksi akibat adanya proses penghilangan mineral akibat bakteri di permukaan gigi disebut dengan karies [4]. Bakteri Streptococcus mutans ini dapat memfermentasi karbohidrat menjadi asam sehingga pH permukaan gigi menjadi turun sehingga terjadi karies. Pencegahan karies bisa dilakukan dengan beberapa hal, salah satunya penggunaan mouthwash [5].

Mouthwash termasuk sediaan cair yang digunakan sebagai pembersih untuk meningkatkan estetika, kesehatan rongga mulut, dan keseragaman nafas [6]. Mouthwash lebih efektif dibandingkan sikat gigi, hal ini mampu menjangkau tempat yang sulit dibersihkan dan dapat mencegah pembentukan plak pada gigi [5]. Mouthwash ini terdiri dari zat berkhasiat antibakteri digunakan sebagai pembilas rongga mulut sehingga mampu mengurangi jumlah mikroorganisme dalam mulut [7]. Pada umumnya telah banyak ditemukan sediaan mouthwash komersial tetapi mengandung kadar alkohol yang cukup tinggi, sehingga hal ini dapat meningkatkan sekitar 50\% risiko timbulnya kanker faring, mulut dan tenggorokan [8].

Alternatif lain yang dijadikan sebagai antiseptik mulut adalah buah nanas. Pada buah nanas terdapat salah satunya enzim bromelin yang berperan penting untuk mengatasi masalah yang terjadi pada mulut. Enzim bromelin memiliki mekanisme kerja mengurai protein dan juga bersifat antimikrobial [9]. Selain itu buah nanas juga mengandung fenol, iodium, fenol dan flavonoid. Hal ini dibuktikan dari hasil penelitian Rakhmanda [10] menunjukkan bahwa konsentrasi minimal jus nanas yaitu 25\% masih dapat menghambat bakteri Streptococcus mutans, sedangkan konsentrasi $100 \%$ jus nanas mempunyai efek bakterisidal. Penelitian lain juga telah menguji efektivitas kandungan antibakteri buah nanas (Ananas comosus L.Merr) yang diperoleh hasil konsentrasi 50\% dengan zona hambat $10 \mathrm{~mm}$ yang termasuk kategori sedang dalam menghambat aktivitas bakteri [9].

Dari uraian di atas, dimana penggunaan mouthwash komersil dengan kandungan alkohol sebesar $25 \%$ atau lebih dapat meningkatkan risiko timbulnya kanker mulut maka dicari alternatif lain dalam pembuatan sediaan mouthwash. Berdasarkan penelitian diatas terkait buah

1,2, 3 Universitas Megarezky, Indonesia 
nanas yang dapat menghambat bakteri Streptococcus mutans maka permasalahan yang timbul yaitu apakah jus buah nanas dapat diformulasikan sebagai sediaan mouthwash dan aktivitas terhadap bakteri Streptococcus mutans. Sehingga hal ini bisa dijadikan alternatif baru dalam pembuatan sediaan mouthwash yang aman digunakan sehari-hari.

\section{Metode Penelitian}

\section{Desain, tempat dan waktu}

Penelitian ini merupakan jenis penelitian eksperimental dimulai dengan pembuatan sediaan mouthwash dan pengujian terhadap bakteri Streptococcus mutans. Penelitian dilaksanakan di Laboratorium Teknologi Farmasi dan Mikrobiologi Farmasi Universitas Megarezky selama Agustus - September 2020.

\section{Bahan dan alat}

Bahan yang digunakan dalam penelitian ini adalah air suling, alumunium foil, biakan murni bakteri Sterptococcus mutans, gliserin, kapas, kertas whatman, , medium NA, menthol,methyl paraben, Nacl 0,9\%, paper disk, buah nanas (Ananas comosus L.Merr).

Alat yang digunakan antara lain : autoklaf $\left(\mathrm{Gea}^{\circledR}\right)$, batang pengaduk, cawan petri (Pyrex $\left.{ }^{\circledR}\right)$, erlenmeyer $\left(\right.$ Pyrex $^{\circledR}$ ), gelas kimia $\left(\right.$ Pyrex $^{\circledR}$ ), gelas ukur $\left(\right.$ Pyrex $^{\circledR}$ ), inkubator (Eyela SLI-400 ${ }^{\circledR}$ ), jangka sorong (Tricle brand ${ }^{\circledR}$ ), LAF, lampu spritus, mortir, tabung reaksi (Pyrex ${ }^{\circledR}$ ), ose, oven (She $\mathrm{Lab}^{\circledR}$ ), pencadang baja, pipet tetes, timbangan analitik (Ohaus ${ }^{\circledR}$ ).

\section{Pengolahan sampel}

Pembuatan jus buah nanas dilakukan dengan cara buah nanas (Ananas comosus L.Merr) segar, dikupas, di cuci dan dipisahkan dari biji dan bonggolnya. Kemudian dipotong kecil-kecil lalu diblender, selanjutnya disaring unrtuk mendapatkan jus buah yang murni [7]. Setelah itu dibuat rancangan formula sediaan mouthwash berdasarkan variasi konsentrasi jus buah nanas $5 \%$ (F1), 10\% (F2), dan 15\% (F3).

\section{Formulasi sediaan mouthwash}

Tabel 1. Rancangan formulasi mouthwash

\begin{tabular}{llllll}
\hline & & \multicolumn{4}{c}{ Konsentrasi \% } \\
Bahan & Fungsi & F0 & F1 & F2 & F3 \\
\hline Jus buah nanas & Zat berkhasiat & 0 & 5 & 10 & 15 \\
Sodium lauryl sulfat & Surfaktan & 0,1 & 0,1 & 0,1 & 0,1 \\
Natrium benzoat & Pengawet & 0,2 & 0,2 & 0,2 & 0,2 \\
Gliserin & Humektan & 15 & 15 & 15 & 15 \\
Menthol & Penyegar & 0,2 & 0,2 & 0,2 & 0,2 \\
Air suling & Pelarut & Ad 100 & Ad 100 & Ad 100 & Ad 100 \\
\hline
\end{tabular}

Ket:

F0 : Mouthwash tanpa jus buah nanas

F1 : Mouthwash dengan jus buah nanas konsentrasi 5\%

F2 : Mouthwash dengan jus buah nanas konsentrasi $10 \%$

F3 : Mouthwash dengan jus buah nanas konsentrasi 15\%

Mouthwash dibuat dengan cara sodium lauryl sulfat digerus dengan air suling secukupnya sampai homogen, kemudian ditambahkan natrium benzoat, gliserin dan jus buah nanas. Menthol dilarutkan terlebih dahulu dengan etanol 70\% hingga homogen lalu dimasukkan pada campuran pertama kemudian dicukupkan volumenya dengan air suling. Disaring hasil larutan menggunakan kertas whattman untuk mendapatkan hasil yang jernih. Ditambahkan pipper mint oil dan FDC yellow no.6 secukupnya untuk memberi aroma dan warna yang menarik sebelum akhirnya dikemas dalam wadah. 


\section{Evaluasi mouthwash}

\section{Uji kestabilan fisik sediaan}

Uji stabilitas fisik sediaan dilakukan dengan cara Cycling test. Sediaan larutan mouthwash disimpan pada suhu $4^{\circ} \mathrm{C} \pm 2^{\circ} \mathrm{C}$ selama 24 jam lalu keluarkan dan tempatkan pada suhu $40^{\circ} \mathrm{C} \pm$ $2^{\circ} \mathrm{C}$ selama 24 jam. Perlakuan ini adalah satu kali siklus. Percobaan diulang sebanyak 6 siklus [11].

\section{Pengamatan Organoleptis}

Uji organoleptis meliputi pengamatan kejernihan, warna dan bau. Mouthwash yang stabil harus menunjukkan karakter yang sama berupa kejernihan, warna dan bau yang sama setelah penyimpanan dipercepat [12].

\section{Bobot Jenis}

Uji bobot jenis dilakukan guna mengetahui kemurnian suatu sediaan dengan menghitung berat jenisnya, jika berat jenisnya mendekati nilai yang telah ditentukan maka dapat dikatakan sediaan memiliki kemurnian yang tinggi. Hal ini dilakukan dengan cara bersihkan dan keringkan pikno kemudian timbang pikno kosong lalu timbang pikno lain berisi air dengan suhu $25^{\circ} \mathrm{C}$. Dilakukan perhitungan bobot air setelah itu buang air dalam pikno dan bersihkan dengan etanol kemudian keringkan. Dilakukan perhitungan bobot pikno berisi zat cair uji [12].

\section{Pemeriksaan pH}

Sediaan yang sudah jadi, sebelum dan sesudah kondisi penyimpanan dipercepat, diukur $\mathrm{pH}$ sediaan dengan menggunakan kertas $\mathrm{pH}$ universal, dimana ujungnya dicelup pada mouthwash kemudian dilihat hasil pengukurannyadengan menyesuaikan ketentuan yang tertera pada wadah kertas $\mathrm{pH}$ [12].

\section{Uji Aktivitas Antibakteri}

\section{a. Sterilisasi alat}

Alat-alat yang akan digunakan terlebih dahulu dicuci dengan detergen kemudian dibilas dengan air suling. Alat-alat yang terbuat dari gelas dibungkus dengan kertas hvs putih dan disterilkan dengan menggunakan oven dengan suhu $180^{\circ} \mathrm{C}$ selama 2 jam. Alat-alat logam disterilkan dengan menggunakan lampu spiritus selama 30 detik. Alat-alat karet dan plastik (tidak tahan pemanasan suhu tinggi) disterilkan dengan autoclaf pada suhu $121^{\circ} \mathrm{C}$ selama 15 menit [12].

\section{b. Penyiapan Medium Nutrient Agar}

Sebanyak 2,8 gram nutrient agar dilarutkan dengan air suling hingga $100 \mathrm{ml}$ dalam labu erlenmeyer kemudian dipanaskan hingga larut. Setelah itu disterilkan selama 15 menit pada suhu $121^{\circ} \mathrm{C}$ dalam autoclaf [12].

\section{c. Peremajaan Kultur Murni Bakteri Streptococcus mutans}

Biakan murni bakteri Streptococcus mutans diambil dan diinokulasi dengan cara menggoreskan pada agar miring pada medium nutrient agar secara aseptis, kemudian diinkubasi selama 24 jam pada suhu $37^{\circ} \mathrm{C}[12]$.

\section{d. Uji Aktivitas Antibakteri Mouthwash Jus Buah Nanas (Ananas comosus L.Merr)}

Pada cawan petri dimasukkan sebanyak $10 \mathrm{ml}$ medium nutriet agar kemudian didinginkan hingga suhu $40^{\circ}-45^{\circ} \mathrm{C}$ hingga memadat. Biakan bakteri yang telah diremajakan kemudian diambil menggunakan lidi kapas steril dan digoreskan pada permukaan medium nutrient agar yang telah memadat secara zigzag dan merata. Pengujian dilakukan dengan menggunakan paper disk yang telah dicelupkan ke dalam sediaan mouthwash kemudian diletakkan diatas medium pada cawan petri secara aseptis. Tiap paper disk dicelupkan dengan mouthwash jus buah nanas (Ananas comosus L. Merr) dengan konsentrasi 5\%; 10\%; dan 15\% dan dibandingkan dengan kontrol negatif (mouthwash tanpa ekstrak) dan kontrol positif (mouthwash komersial). 
Kemudian masing-masing cawan petri diinkubasi selama 24 jam pada suhu $37^{\circ}$ C. Pengujian dilakukan sebanyak 3 kali replikasi. Setelah itu diukur rata-rata diameter zona hambat yang dihasilkan menggunakan jangka sorong [12].

Hasil Penelitian

Tabel 2. Hasil pemeriksaan bobot jenis

\begin{tabular}{lll}
\hline No. & Sediaan & Bobot Jenis $(\mathrm{g} / \mathrm{ml})$ \\
\hline 1 & F1 & 1,081 \\
2 & F2 & 1,078 \\
3 & F3 & 1,076 \\
\hline
\end{tabular}

Ket:

F1 : Mouthwash dengan jus buah nanas konsentrasi 5\%

F2 : Mouthwash dengan jus buah nanas konsentrasi 10\%

F3 : Mouthwash dengan jus buah nanas konsentrasi 15\%

Tabel 3. Hasil evaluasi sediaan sebelum cycling test

\begin{tabular}{lllllll}
\hline \multirow{2}{*}{ No } & \multirow{2}{*}{ Evaluasi } & Fo & F1 & F2 & F3 & KP \\
\hline 1 & Bentuk & larutan & larutan & larutan & larutan & larutan \\
2 & Warna & kuning & kuning & kuning & kuning & kuning \\
3 & Bau & khas & khas & khas & khas menthol & khas \\
& & menthol & menthol & menthol & & menthol \\
4 & Kejernihan & jernih & jernih & jernih & jernih & jernih \\
5 & pH & 5,4 & 4,9 & 6,0 & 6,3 & 5,2 \\
\hline
\end{tabular}

Ket:

F0 : Mouthwash tanpa jus buah nanas

F1 : Mouthwash dengan jus buah nanas konsentrasi 5\%

F2 : Mouthwash dengan jus buah nanas konsentrasi 10\%

F3 : Mouthwash dengan jus buah nanas konsentrasi 15\%

KP : Mouthwash komersil dengan merk 'X'

Tabel 3. Hasil evaluasi sediaan setelah cycling test

\begin{tabular}{lllllll}
\hline \multirow{2}{*}{ No } & \multirow{2}{*}{ Evaluasi } & \multirow{2}{c}{ Setelah cycling test } & \multirow{2}{*}{ F2 } & F1 & F2 & KP \\
\hline 1 & Bentuk & larutan & larutan & larutan & larutan & larutan \\
2 & Warna & kuning & kuning & kuning & kuning & kuning \\
3 & Bau & khas & khas & khas & khas menthol & khas \\
& & menthol & menthol & menthol & & menthol \\
4 & Kejernihan & jernih & jernih & jernih & jernih & jernih \\
5 & pH & 5,6 & 4,7 & 6,2 & 6,4 & 5,3 \\
\hline
\end{tabular}

Ket:

F0 : Mouthwash tanpa jus buah nanas

F1 : Mouthwash dengan jus buah nanas konsentrasi 5\%

F2 : Mouthwash dengan jus buah nanas konsentrasi $10 \%$

F3 : Mouthwash dengan jus buah nanas konsentrasi 15\%

$\mathrm{KP}$ : Mouthwash komersil dengan merk 'X' 


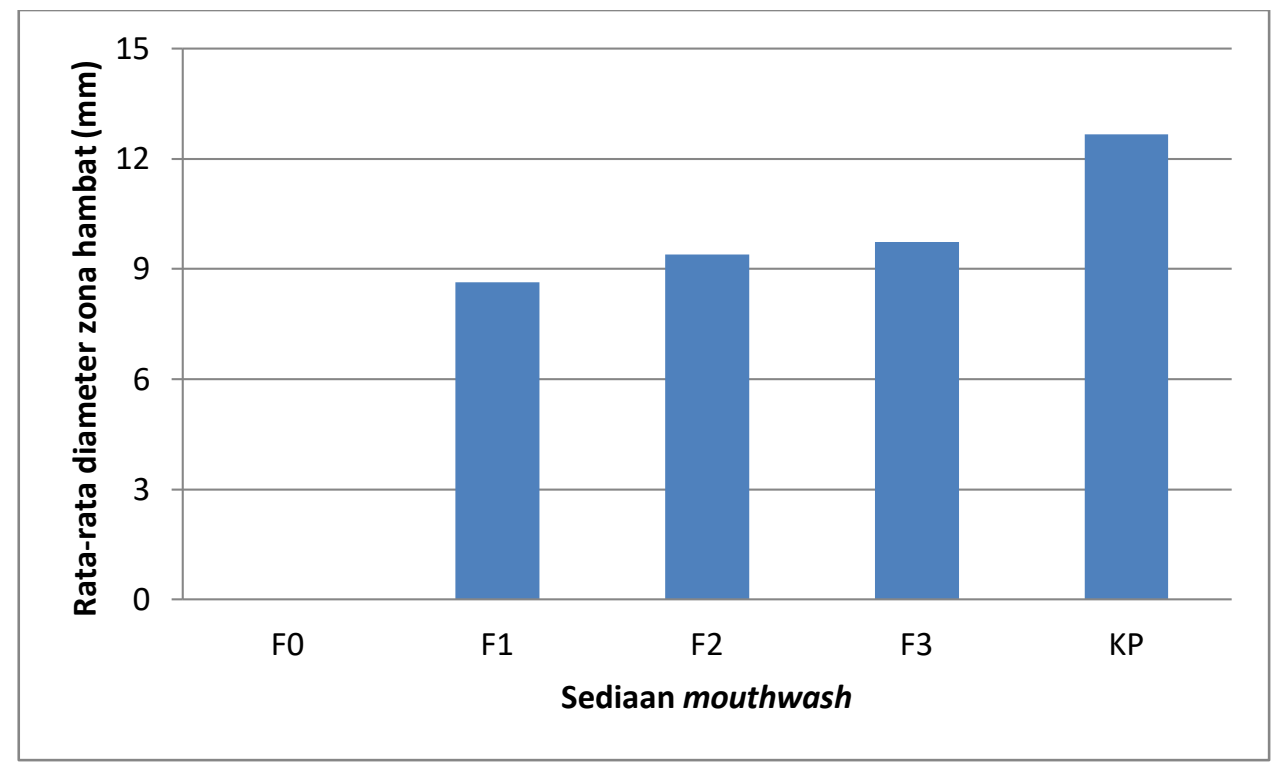

Gambar 1. Diagram zona hambat

Ket:

F0 : Mouthwash tanpa jus buah nanas

F1 : Mouthwash dengan jus buah nanas konsentrasi 5\%

F2 : Mouthwash dengan jus buah nanas konsentrasi 10\%

F3 : Mouthwash dengan jus buah nanas konsentrasi 15\%

$\mathrm{KP}$ : Mouthwash komersil dengan merk 'X'

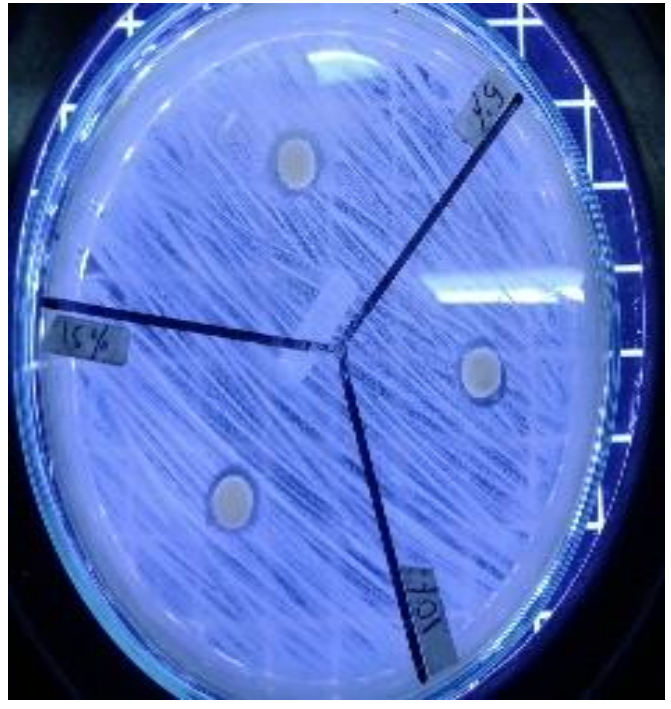

Gambar 2. Uji aktivitas antibakteri formulasi mouthwash

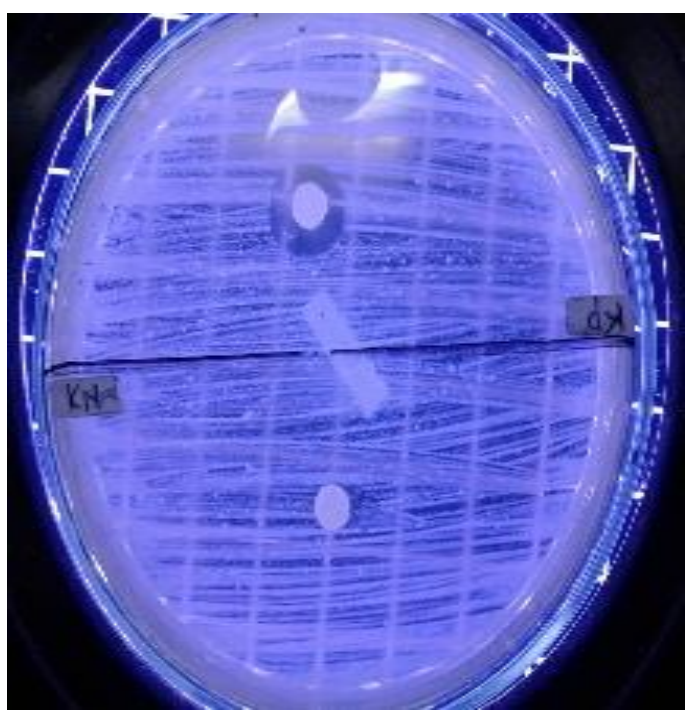

Gambar 3. Uji aktivitas antibakteri kontrol mouthwash

\section{Diskusi}

Penelitian ini dimulai dengan pembuatan jus buah nanas dengan cara buah nanas dikupas dan dipisahkan antara daging dengan biji dan bonggolnya. Setelah itu, daging kemudian dipotongpotong kecil untuk memudahkan saat dihaluskan. Proses ini dilakukan agar jus buah yang diperoleh lebih banyak. Setelah proses penghalusan selesai, kemudian disaring menggunakan kain kasa untuk memisahkan filtrat dan residu. Jus buah yang dihasilkan kemudian disaring 
kembali menggunakan kertas whattman sehingga menghasilkan jus buah sebagai zat berkhasiat dalam pembuatan mouthwash.

Mouthwash mengandung zat berkhasiat antibakteri untuk mengurangi jumlah mikroorganisme sehingga disebut juga larutan antiseptik mulut. Zat berkhasiat antibakteri pada mouthwash dapat berupa sintetis atau berasal dari bahan alam [7]. Pada penelitian ini formulasi mouthwash terdiri dari sodium lauryl sulfat, natrium benzoat, menthol, gliserin, dan pipper mint oil serta air suling untuk melarutkan bahan dan mencukupkan volume yang diinginkan. Natrium benzoat dimaksudkan sebagai pengawet untuk mencegah kerusakan dan pertumbuhan mikroorganisme pada sediaan. Penambahan menthol yang berbau khas permen dapat memberikan sensasi dingin atau menyegarkan sehingga digunakan sebagai penyegar. Gliserin sendiri dimaksudkan untuk menjaga zat aktif agar tidak menguap dengan cara mengikat bahan aktif dan sekaligus mempertahankan air yang ada pada sediaan sehingga dapat memperbaiki stabilitas bahan dalam jangka panjang. Selain itu gliserin juga dijadikan sebagai pemanis, hal ini disebabkan karena gliserin 0,6 kali lebih manis dibanding sukrosa [13].

Setelah formulasi mouthwash, kemudian dilanjutkan dengan evaluasi sediaan salah satunya mengetahui bobot jenis. Hal ini berguna untuk mengetahui kemurnian suatu sediaan dengan menghitung berat jenisnya, jika berat jenisnya mendekati nilai yang telah ditentukan maka dapat dikatakan sediaan memiliki kemurnian yang tinggi (12). Selain itu pengujian bobot jenispun dilakukan untuk mengetahui kemurnian suatu sediaan, jika bobot jenisnya mendekati nilai bobot jenis air yaitu $1,00 \mathrm{~g} / \mathrm{ml}$ maka sediaaan dapat dikategorikan memiliki kemurnian yang tinggi, seperti terlihat pada tabel 1. Hasilnya pada pemeriksaan bobot jenis menunjukkan bahwa ketiga formula memiliki bobot jenis yang mendekati bobot jenis air.

Evaluasi sediaan dilanjutkan dengan uji stabilitas sediaan mouthwash pada penyimpanan suhu tinggi dalam hal $40^{\circ} \mathrm{C}$ dan suhu rendah yaitu $4^{\circ} \mathrm{C}$. Uji stabilitas obat atau sediaan perlu dilakukan untuk mengetahui kemampuan produk obat dalam mempertahankan sifat dan karakteristiknya agar sama setelah dibuat dan sepanjang periode penyimpanan [14]. Pada hasil uji stabilitas sediaan menunjukkan bahwa tidak terjadi perubahan signifikan pengamatan evaluasi sediaan pada saat sebelum dan sesudah cycling test. Hasil uji stabilitas evaluasi sediaan sebelum dan sesudah cycling test dapat dilihat pada tabel 2 dan 3.

Penelitian kemudian dilanjutkan dengan uji aktivitas antibakteri sediaan mouthwash jus buah nanas terhadap bakteri Streptococcus mutans. Pengujian dilakukan dengan cara paper disk dicelupkan kedalam masing-masing sediaan bebeda konsentrasi (5\%, 10\% dan 15\%) dan sediaan tanpa zat berkhasiat serta sediaan komersial kemudian diletakkan diatas medium agar seperti gambar 2 dan 3. Hasil pengujian aktivitas antibakteri sediaan mouthwash dapat terlihat seperti pada gambar 1 . Hasil penelitian terlihat pada gambar 1 bahwa F1 $(8,6 \mathrm{~mm}), \mathrm{F} 2(9,4 \mathrm{~mm})$ dan F3 $(9,7 \mathrm{~mm})$ termasuk memiliki kategori memiliki zona hambat sedang sedangkan mouthwash komersial $(12,6 \mathrm{~mm})$ termasuk kategori zona hambat kuat. Hal ini sesuai dengn kategori zona hambat yang menunjukkan bahwa rata-rata diameter 6-10 mm menunjukkan kategori penghambatan sedang sedangkan rata-rata diameter 11-20 mm menunjukkan kategori penghambatan kuat [6].

Kandungan buah nanas antara lain air, besi, iodium, fenol, fosfor, kalium, karbohidrat, klor, lemak, magnesium, natrium, protein, serat, vitamin A dan C. Klor, iodium dan fenol menurut penelitian terdahulu mempunyai efek sebagai antiseptik. Klor dan iodium mempunyai sifat bakterisidal. Mekanisme kerja klor dengan air yaitu membentuk hipoklorit sedangkan iodium dipercaya dapat menggumpalkan protein sehingga bekerja dengan cepat dan hampir semua bakteri pathogen dapat dibunuh. Fenol juga merupakan salah satu antiseptik tertua yang memiliki sifat bakterisidal [10]. Selain itu, buah nanas juga memiliki kandungan enzim bromelin dengan mekanisme kerja mampu menginaktifkan adesin sel mikroba juga enzim dan mengganggu transpor protein pada lapisan dalam sel sehingga memiliki aktivitas antibakteri. Enzim bromelin diketahui juga memiliki target pada polipeptida dinding sel, hal ini 
menyebabkan pembentukan dinding sel menjadi kurang sempurna sehingga sel bakteri menjadi lisis akibat tekanan osmotic maupun fisik [9].

\section{Kesimpulan}

Hasil penelitian menunjukkan bahwa formula mouthwash jus buah nanas (Ananas comous L.Merr) dengan perbandingan konsentrasi 5; 10\%; dan 15\% menunjukkan bahwa tidak terjadi perubahan baik setelah uji kestabilan secara bentuk, warna, bau, kejernihan dan $\mathrm{pH}$. Uji aktivitas mouthwash terhadap bakteri Streptococcus mutans menunjukkan rata-rata diameter zona hambat terhadap bakteri Streptococcus mutans pada konsentrasi 5\%; 10\%; dan 15\% masing-masing sebesar 8,6 mm; 9,4 mm; dan 9,7 mm yang termasuk katergori zona hambat sedang.

\section{Daftar Pustaka}

1. Elmitra, Ramadhani N. Formulasi Obat Kumur Dari Daun Asam Jawa (Tamarindus indica L.) Dengan Metode Infundasi. Borneo Journal of Pharmascientech. 2017;1(2).

2. Andayani NP, Artawa IMB. Pengaruh Penyakit Gigi dan Mulut Terhadap Halitosis. Jurnal Kesehatan Gigi. 2016;4(1):24-48.

3. Andayani R, Chismirina S, Kumalajus I. Pengaruh Ekstrak Buah Belimbing Wuluh (Averrhoa bilimbi) Terhadap Interaksi Streptococcus sanguinis dan Streptococcus mutans Secara In Vitro. Cakradonya Dent Journal. 2014;6(2): 678-744.

4. Mustika MD, Carabelly AN, Cholil. Insidensi Karies Gigi Pada Anak Usia Prasekolah di TK Merah Mandiangin Martapura Periode 2012-2013. Dentino Jurnal Ked. Gigi. 2014; 2(2): 200-204.

5. Sakinah N, Dwyana Z, Tambaru E, Rante H. Uji Aktivitas Sediaan Obat Kumur Ekstrak Daun Miana Coleus scuttelariodes (L.) Benth Terhadap Pertumbuhan Bakteri Streptococcus mutans. Jurusan Biologi Universitas Hasanuddin. 2015.

6. Handayani F, Warnida H, Nur SJ. Formulasi dan Uji Aktivitas Antibakteri Streptococcus mutans Dari Sediaan Mouthwash Ekstrak Daun Salam (Syzygium polyanthum (Wight) Walp.) Media Sains. 2016;9(1): 74-84.

7. Ririn, Tandjung AI, Wagola S. Formulasi Sediaan Mouthwash Dari Jus Buah Sirih (Piper betle L.) Varietas Siriboah. As-Syifaa. 2013;5(2):153-161.

8. Gurning D, Nathaniel D, Mella O, Sagala Z. Uji Aktivitas Antibakteri Sediaan Obat Kumur Dari Ekstrak Etanol 70\% Batang Sambung Nyawa(Gynura procumbens (Lour.) Merr.) Terhadap Bakteri Streptococcus mutans. Pharmacon: Jurnal Farmasi Indonesia. 2018;15(2): 58-64.

9. Bahtiyar AY, Efriyadi O, Fitriah E. Efektivitas Kandungan Anti-Bakteri Buah Nanas (Ananas comosus L.Merr) dalam Menghambat Pertumbuhan Bakteri Streptococcus mutans. Prosiding Semnas Sains \& Entrepreneurship IV. 2017:634-640.

10. Rakhmanda AP. Perbandingan Efek Antibakteri Jus Nanas (Ananas comosus L.Merr) pada Berbagai Konsentrasi Terhadap Streptococcus mutans. Fakultas Kedokteran Universitas Diponegoro. 2008.

11. Nofita H, Mugiyanto E, Agustiningrum W. Uji Antibakteri Formulas Sediaan Mouthwash Ekstrak Kulit Buah Nanas (Ananas comosus L. Merr) Terhadap Bakteri Staphylococcus aureus. Journal of Current Pharmcautical Sciences. 2018;2(1):97-103.

12. Simbolon PM, Hartina ST. Formulasi dan Uji Aktivitas Sediaan Mouthwash Ekstrak Etanol Bawang Dayak (Eleutherine palmifolia (L.) Merr) Sebagai Antibakteri terhadap Streptococcus mutans. Program Studi Farmasi STIKes Mega Rezky Makassar. 2017.

13. Rowe CR, Sheskey PJ, Quinn ME. Handbook of Pharmaceutical Excipient. Sixth Edition. UK: Pharmaceutical Press; 2009.

14. Nurhadi G. Pengaruh Konsentrasi Tween 80 Terhadap Stabilitas Fisik Obat Kumur Minyak Atsiri Herba Kemangi (Ocimum americanum L.). Program Studi Farmasi. Jakarta : UIN Syarif Hidayatullah. 2015.

15. Kono SR, Yamlean PVY, Sudewi S. Formulasi Sediaan Obat Kumur Herba Patikan Kebo (Euphorbia hirta) dan Uji Antibakteri Prophyromonas gingivalis. Pharmacon Jurnal Ilmiah Farmasi-UNSRAT. 2018;7(1):37-46. 